\title{
TEACHING THE UKRAINIAN LANGUAGE TO FOREIGNER STUDENTS WITH THE TEXTS OF NEWS CHRONICLES
}

\section{Zanko O. V.}

\section{INTRODUCTION}

The article considers the features of the media text of news chronicles as a material for teaching reading to foreign students. The expediency of using the method of creating speech models of media texts of news chronicles is analyzed, which will allow students to systematize lexical material, structure it in accordance with certain components of the text structure, master the semantic structure of the text with its specific language features. The mechanisms of practicing reading with the help of speech models of media text and production of other skills related to both reception (model as a reference point when reading a text) and reproduction (model as a reference point when translating a text) are clarified.

The importance of researching mass media texts in the field of teaching Ukrainian to foreigner students is obvious as the events taking place today in any country of the world will become the property of the whole planet tomorrow thanks to the work of the media. A modern person cannot imagine their life without the use of a global information system, which is why the problem of quality reading of the media, which include online publications and the press, is becoming relevant.

The peculiarity of the current stage of development of society is that information has become the main resource of development. The relevance of the topic of this study lies not only in the linguistic field as it also is one of the sources of local history and historical knowledge of the Ukrainian language because online publication along with the press today is not a unique environment for the dissemination and functioning of the media. The value of information on the Internet lies in the natural motivation of its knowledge, which is created by the relevance of the material - up-to-date and accessible information about world events, which is interesting for the network users. The convenience of the Internet environment in teaching Ukrainian as a foreign language is influenced by the fact that each foreign student can independently choose the time and place to use the network, choose ways to obtain information and its volume.

Today, one of the most important strategies of international relations is carried out through mass media and media texts - business communication. 
That is why the issue of speech competence of future specialists in law, political science, sociology, journalism is becoming relevant.

The purpose of the article is to substantiate the need to teach reading of the texts of news chronicles of online publications / press in Ukrainian using speech models of texts of a certain type.

The leading didactic task of our research is to solve the problem of improving the effectiveness of classes on the formation of reading skills of foreign students in Ukrainian, using the method of separating linguistic and semantic units.

\section{Features of the media text of news chronicles as a material for teaching reading to foreign students}

The problem of methods of teaching reading in a foreign language is presented in the scientific works of many domestic and foreign scholars who have studied various aspects of teaching reading, in particular the cultural and historical development of personality covered in the works of O. Asmolov, L. Vygotskyi, O. Leontiev, etc. Mechanisms of coding and decoding of speech were considered in the works of M. Zhynkin, O. Zalevskaya, I. Zymniaya. The works of V. Belianin, I. Halperyn, T. Drydze, K. Sedov, and others are devoted to the peculiarities of the linguistics of the text. The processes of perception and understanding in reading have become the subject of scientific research of such famous linguists as A. Sokolova, O. Leontiev and I. Zymniaya.

Ukrainian as a foreign language is a relatively young branch of linguistics. Modern research in the field of teaching Ukrainian as a foreign language is reflected in the scientific works of L. Bei, T. Yefimova, I. Kochan, D. Mazuryk, T. Laguta, A. Chistiakova, B. Sokil, O. Trostynska and many other linguists. The latest research on this issue is G. Boyko's scientific research, which covers methods for improving the reading skills of foreign students in Ukrainian as a foreign language. In the article, the author focuses on the benefits of personality-oriented learning and improving the skills of reading of science texts by foreign students of technical specialties in the 1-2 years of studies. The researcher proposes to distinguish five stages of development of reading skills, identifies the basic principles of students' interest in reading and learning interesting information, as well as names certain skills that should be acquired by a university student.

In "Types of reading in the course of Ukrainian as a foreign language" N. Stankevich rightly emphasizes that "learning to read is a complex and long process. They start with reading in order to voice the language material, practice pronunciation, stress words, develop correct intonation, etc. Then reading pursues communicatively pragmatic goals, and gradually foreign students develop an attitude towards it as a way to obtain information. It is 
important for the teacher to combine skillfully all the above types of reading in the learning process. Then the student learns to freely combine them independently, and these are steps towards mature and mobile reading as a pragmatic, aesthetic, culturological problem"1. However, methodological developments in teaching reading to foreign students today are few, in particular based on informative texts of online publications / printed press.

Traditional basis for teaching to read news-chronicles and texts devoted to socially important topics ("Politics", "Economics", "Culture", "Sports", "Health") in the process of teaching foreign students is selection and presentation of a thematically conditioned tokens and stable speech inversions (clichés) that characterize the journalistic style of the modern Ukrainian language. Creating thematic dictionaries (lists of words, phrases and clichés) is certainly useful and mandatory in the process of learning to read and understand the texts of news chronicles, but, as we see from experience, it is not effective enough.

The above necessitates the study of the text of news media chronicles from the standpoint of psycholinguistics, as it takes into account the context factor (the main feature of psycholinguistics) -situation (a fragment of reality with appropriate social conditions). O. Selivanova considers the problem of perception of the text in connection with its generation, as the processes that take place during perception are considered convertible processes of text production ${ }^{2}$.

The style and genre of the media text are actively discussed in the modern scientific world. The text is studied in a range of sciences, such as literary studies, psychology, semiotics, history, ethnography, rhetoric, logic, pragmatics, hermeneutics and anthropology. There is no single definition of the text, as there is no common view among all researchers as to what the text is as an object of in linguistics. In our opinion, the researcher N.G. Ishchenko in the article "Text - a holistic linguistic and speech structure" analyzed a wide range of interpretations of the concept of "text" as a subject of scientific research of many linguists: Yu.M. Lotman, E. Benvenista, V. Vinogradov, M. Bakhtin, O. Leontiev, M. Zhynkin, etc., who considered the text from the standpoint of semiotics, discourse, psycholinguistics, pragmatics, etc.:

- semiotically, as a verbal sign system in aspects of its content: structural, semantic, functional; paradigmatics and syntagmatics (scientists:

${ }^{1}$ Станкевич Н.І. Види читання в курсі української мови як іноземної. Теорія і практика викладання украӥнської мови як іноземної. 2013. Вип. 8.186 с.

2 Селіванова О. «Сучасна лінгвістика: Напрями та проблеми», підручник. Полтава : Довкілля-К, 2008. 713 с. 
R. Jacobson, Yu. M. Lotman, B.Ya. Uspenskyi, A.G. Baranov, V.G. Gak, L.M. Loseva);

- discursively in the characteristics of interdisciplinary fields of knowledge (E. Benvenist, T.A. van Dyck, early R. Bart);

- linguistically in the system of functional meanings of language units (V.V. Vinogradov, G.O. Vynokur, V.P. Grygoriev, G.Y. Solganyk, L.A. Novikov);

- pragmatically, depending on speech situations (J. Austin, J. Searle, M.M. Bakhtin, N.D. Artyunova);

- cognitively, as a set of concepts and ideas related to certain areas of language use (G. Deleuze, Yu. Kristeva, R. Bart);

- naratologically within the theory of communication as an active dialogic interaction of writer and reader (W. Propp, W. Shklovsky, B. Eichenbaum, M.M. Bakhtin, P. Lubbock, N. Friedmann, E. Leibfried, W. Früger);

- psycholinguistically, as a dynamic system of language formation and its perception (L.S. Vygotskyi, O.R. Luria, M.I. Zhynkin, T.M. Dridze, O.O. Leontiev);

- psychophysiologically, as a multidimensional phenomenon that implements the psychology of the author in a certain literary form by language (O.I. Dibrova, N.O. Semenova, I. Filippova) ${ }^{3}$.

Thus, the above information shows how diverse scholars consider the text. The phenomenon of the text lies in its multifacetedness, systemacy, due to the structure, hierarchy, integrity and relationship with the environment, which belong to the invariant features of this multidimensional phenomenon $^{4}$. Scientists, especially O. Leontiev, note that native speakers when reading the text primarily perceive its semantic structure while people who do not know the language well enough (level A, A1, B), pay attention to individual speech constructions 5 .

Given the above, a productive direction in teaching foreigners students to read the texts of news chronicles of online publications / printed press is to study the semantic structure of the text, its relationship with the relevant speech models. One of the leading factors that determines the effectiveness

${ }^{3}$ Іщенко Н.Г. Текст - цілісна мовна й мовленнєва структура. Науковий вісник ДДПГУ імені І. Франка. Серія «Філологічна». Мовознавство. Том 1. № 5, 2016. Вип. 62.129 с.

${ }^{4}$ Іщенко Н.Г. Текст - цілісна мовна й мовленнєва структура. Науковий вісник ДДПГУ імені І. Франка. Серія «Філологічна». Мовознавство. Том 1. № 5. 2016. 129 с.

5 Леонтьев А.А. Восприятие текста как психологический процесс. Психолингвистическая и лингвистическая природа текста и особенности его восприятия. Київ, 1979. 23 с. 
of text comprehension is its structural and semantic organization, which organizes and directs the process of perception and understanding of the message, ensuring the reader's interaction with the text ${ }^{6}$. In this case, the text acts not just as a language unit, but also as a product of the author's active work in organizing not only the content of the message, but also embedding in the text of the program its perception and understanding by the reader. This is the essence of the psychological approach to the study of the text, which, in contrast to the linguistic one, involves entering a non-textual reality, reflecting in its structure the interaction of the author and the reader. The text models the interaction between the author and the reader, reflecting, on the one hand, the communicative intention of the author, on the other the communicative-cognitive activity of the reader. Important characteristics of the work, such as structure, informativeness and dialogicity, allow not only to control the processes of understanding and comprehension of the work, but also to provide dialogic contact between the author and the reader, thus contributing to semantic, creative understanding of the text ${ }^{7}$. The Ukrainian language encyclopedia states that text (from Latin textum connection, combination, fabric) - is a written or oral speech array, which is a linear sequence of statements, combined in the short term semantic and formal-grammatical connections, and in general compositional terms - a common thematic and plot task ${ }^{8}$.

In psycholinguistic theory, any consistent expression of any content is considered as the text.

The object of our research is the text of the news chronicle of online publications / printed press. O. Selivanova in her research identifies types / genres of texts ${ }^{9}$. Texts are classified according to the following parameters: by the form of speech presentation; by the styles and genres; by the form of communication; by the way of presentation; by the expressiveness of speech $^{10}$. This study analyzes the interpretation of the text, its features in terms of material form - news-chronicles of the printed press or online publications.

In the process of teaching foreign students to read news texts, it is advisable to analyze speech-semantic models of the text, i.e. to identify

\footnotetext{
${ }^{6}$ Чепелєва Н.В. Текст і читач: посібник. Житомир : Вид-во ЖдУ імені І. Франка, 2015. C. 67.

${ }^{7}$ Чепелєва Н.В. Там само.

${ }^{8}$ Українська мова. Енциклопедія. Київ, Українська енциклопедія ім. М. Бажана. 2000. C. 254.

9 Селиванова О. Сучасна лінгвістика: напрями та проблеми : підручник. Полтава. 2010. С. 508.

${ }^{10}$ Селиванова О. Там само.
} 
elements of the semantic structure of the text and further identify the elements through speech forms / models that embody them. To create such constructions, it is recommended to divide the text into lexical-semantic units, i.e. in such a way that there is a connection between the essence of the text and the speech model that expresses it. This type of text has a clear direction of construction with fixed elements at the grammatical and lexical levels. According to O. Selivanova, texts, based on the degree of stability of the textual content of language elements are divided into three types: 1) tough (clichéd); 2) usual (partially regulated) and 3) free ${ }^{11}$.

An example of a tough clichéd text is: «Україна та Угоршина планують створити робочу групу щодо украӥнського закону про освіту. Як інформує УМ, про це заявив міністр закордонних справ Угорщини Петер Сійярто на спільному брифінгу з українським колегою Дмитром Кулебою».

The text of news chronicles of online publications / printed press can be identified, in our opinion, as tough (clichéd). The rigidity of the construction of a news text is caused by extra linguistic factors, namely: social, geographical, socio-historical, cultural, ethnic, etc. The purpose of the text of the news chronicle - adequate transmission of operational information to the reader - has led to the requirement of accuracy, which ensures the adequacy of perception provided the efficiency of information assimilation. These factors determine the production of standardization of the text, i.e. its structure is correlated with a certain functional speech model. For example, in the abovementioned text, which informs about a certain event, there is a fixed sequence of lexical-semantic units, which are expressed in certain clichés: agents (Украӥна та Угорщина планують створити) - content (щодо українського закону про освіту) - source (як інформує УМ) - link (про ие заявив міністр закордонних справ Угорщини Петер Сійярто) - time / place (на спільному брифінгу з украӥнським колегою Дмитром Кулебою).

The rigidity of the construction of the text of the news chronicle is due to its conciseness, which is achieved through both the linguistic means that formalize it and the condensation of information. Registration of the maximum information by the minimum linguistic means promotes fixing of a parity of elements of semantic structure and means of their lexical embodiment. In modern linguistics, there is a discussion concerning definition of style of similar texts, so I.G. Cherednichenko, describing the style of the mass press, distinguishes between informational and journalistic ${ }^{12}$; V.V. Zaitseva proposes a new functional style - informational

\footnotetext{
${ }^{11}$ Там само. 508 c.

12 Чередниченко І.Г. Стиль масової преси. Нариси 3 загальної стилістики сучасної української мови. Київ, 1962. С. 51-52.
} 
one. The question of the status of the newspaper style is debatable, as it can be realized in short informational messages and headlines ${ }^{13}$ : «Дніпро: Коронували особливих; Луцьк: Готують собі студентів.; Кропівницький: Повертаються до книжки»; «Відлуння Другої світової: на Тернопільщині розкопали літак США».

"Language of newspapers", as scholars note, is a multifaceted concept, as all styles of the modern Ukrainian literary language can be present in the columns of a newspaper (a column of an online publication). Some genres are more journalistic in style (propaganda materials), other genres (essay, feuilleton) combine features of journalistic and artistic styles, while others are dominated by features of oral speech (interviews, reports) and so on. A. Ya. Alekseev considers the media style to be a macrosystem that includes such microsystems as newspaper style, journalistic style, broadcasting style, television style, which in turn is divided into types of texts or genres. Thus, the newspaper style includes such genres as: editorial, official communiqué, commentary (political, economic, sports, etc.), chronicle, announcement. Each of these genres, or backgrounds, is characterized by its own linguistic and paralinguistic properties, but they all meet the basic functional criteria of the style to which they belong ${ }^{14}$.

Peculiarities of newspaper texts have been studied by numerous domestic and foreign linguists: V.V. Zaitseva, K.V. Boychuk, M.P. Brandes, Yu.O. Areshenkov, Yu.M. Skrebnev, I.V. Arnold, A.Ya. Alekseev, etc.

The main features of the texts of the "language of newspapers" of the news chronicle of the mass media include: economy of language means, conciseness of presentation with informative saturation; presence of sociopolitical vocabulary and phraseology, use of language stereotypes, clichés; emotionally expressive vocabulary; use of pictorial and expressive means of speech, in particular means of stylistic syntax (rhetorical questions and exclamations, parallelism, repetitions, inversion, etc.). Scientific literature notes the high standardization and expressiveness of the language of news chronicles ${ }^{15}$.

Speaking about the most important features of newspaper materials or online publications, it is appropriate to turn to the scientific research of V.V. Zaitseva, who identifies and analyzes note, essay and leading article.

13 Зайцева В.В. Особливості газетно-публіцистичного стилю. Дослідження з лексикології і граматики української мови. 2001. С. 82-91.

${ }^{14}$ Алексеев А.Я. Сопоставительная стилистика: уч. пособие. Дніпропетровськ, Национальный горный университет. 2012. С. 47.

15 Зайцева В.В. Про жанрову своєрідність газетної мови. Украӥнський смисл. 2015. № 2015. C. 40. 
In her opinion, a note is a linguistic newspaper genre, the functioning of which is based on the following extra lingual factors: 1) the dominant communicative intention of the genre - to promptly report on events, answering three main questions: what? where? when? happened 2) the subject of information - a topical, socially important event; 3) the addressee of the information message - the correspondent of any press body, news agency. Characteristically, the scientist notes, there is no subjective "I" in the note, all attention is focused on the objective reflection of documented events. The brevity of the note determines its compositional structure, its logic, the sequence of sentence construction: each sentence is a continuation of the previous one with the addition of new factual elements of content. The author notes that this type of text does not use stylistic devices such as rhetorical questions, exclamations, etc. The effect of reliability and influence of the material is determined primarily by the reported facts. The informational text uses mainly socio-political vocabulary, terms, geographical names, proper names, job titles, titles, nominations of time as mandatory components of naming events ${ }^{16}$. For example, «Периа y cвimi робот-художниия проведе свою виставку картин. Першого у світі робота-художниџю створили 2019 року. Ї̈ назвали Ай-Да, на честь першої програмістки Ади Лавлейс. У Лондоні в травні в Музеї дизайну відкриється перша виставка робота, пише The Times».

\section{Speech models of lexical and semantic units of the media text}

Knowledge of functional styles of modern Ukrainian language, mastering the relevant vocabulary and speech models, compositional structure of the journalistic text, skills of drawing up interrogative and nominative plans of the text give the opportunity to study the Ukrainian language with foreigners on the basis of news texts.

Studies of informative texts of news chronicles of online publications / printed press considered in this article are based on the scientific work "Lexical and semantic unity in the structure of the text (on the material of the newspaper chronicle)" by a linguist P.V. Khazov ${ }^{17}$. The scientist considers the creation of the models of the text, which are its transformation in the process of perception and reproduction. P.V. Khazov emphasizes that such analysis of texts is important for studying the mechanisms of construction of informative texts, as it makes it possible to identify the

16 Зайцева В.В. Про жанрову своєрідність газетної мови. Украйнський смисл. 2015. № 2015. С. 39.

17 Хазов П.В. Лексико-смысловые единства в строении текста (на материале газетной хроники): дис. ... канд. филол. наук. www/dissercat.com. Языкознание. 1984. $268 \mathrm{c}$. 
national specifics of the text of the news chronicle. Defining certain speech models of informative text will allow foreign students to better understand the semantic structure of the text, determine the language tools that embody it and, accordingly, will teach the holistic perception of a foreign text, taking into account the specific semantic structure.

Analyzing the research of the scientist, we can say that the text of the news chronicle of online publications and the printed press is a holistic morphological structure, built on the laws and norms of a language, organized by a certain system of speech signs. The functioning of these speech signs determines the stability of expression of the elements of semantic structure by a closed number of lexical means, i.e. the presence of lexical-semantic units; stereotyping of their location in the text, as well as the correspondence of elements of the semantic structure of texts to a certain group of events / situations. This, according to scientists, is the standardization of the text of the media.

The choice of means of speech and the very structure of the media text is influenced by the limited amount of such text, the need to contain as much information as possible. The peculiarity of the text of the news chronicle is its structure, i.e. such organization of the text message that allows to convey information quickly, concisely, to report the essence (even if the note is not read to the end) and to influence the reader to some extent. The exposition should not require long-term preparation from the foreign reader, i.e. the dependence on the context (except for the pre-text task - dictionary of new words and phrases of journalistic style / cliché) should be minimal. At the same time, along with the familiar recurring theme, a new and relevant topic emerges.

In his scientific work, P.V. Khazov ${ }^{18}$ identifies three forms of permanent connection between the elements of the semantic structure of the text and their lexical and grammatical embodiment: grammatical (use for one category of elements of the semantic structure of words of one morphological category and phrases that perform one function in a sentence); semantic (use of words and phrases belonging to one lexicalsemantic group to express one category of elements of semantic structure); lexical (use for one element of semantic structure of a closed series of words, phrases). These forms of communication can be both universal variants of lexical-semantic units and used in variants conditioned by certain events. The scientist established the functioning of 15 lexical and semantic units:

18 Хазов П.В. Лексико-смысловые единства в строении текста (на материале газетной хроники) : дис канд. филол. наук. www/dissercat.com. Языкознание. 1984. $175 \mathrm{c}$. 
source, place, time, event, agent, content, purpose, cause, reason, relation, reference, evaluation, result, participation, scale ${ }^{19}$.

Lexical-semantic unity in the text of the news chronicle of Internet publications / printed press is a set of variants of lexical-semantic expression of certain elements of the semantic structure of the text. The lexical and semantic unity of the text analyzed by us can be expressed by one of the options:

1) a toponym: a) a name of acity: «У Парижі в рамках урочистостей з нагоди 60-ї річниці прийняття ООН Загальної декларації прав людини відкрито меморіальну дошку Рафалу Лемкіну, винахідникові терміну «геноцид», повідомляє польська Інформагенція ПАП»; b) a name of a country: «У Нігерї визволили з полону піратів шістьох українських моряків. Сьогодні було звільнено 6 украӥнських моряків-членів екіпажу судна Stevia, яких півтора місяия утримували в піратському полоні в Hizepiï»;

2) a phrase (with the name of a place little-known to the reader), containing: a) a noun denoting a generic concept (region, region, city, district, settlement, river, mountain, island, peninsula, etc.) + name of a city, district, settlements, etc. (toponym). It is possible to include an adjective in the phrase, which means belonging to the country / city, etc .: «На Одещиині опинилася y сніговій пастияі сотня вантажівок. Близько сотні вантажівок застрягли у трьох снігових пастках на трасі М-05 в Одеській області у п'ятницю. Попри безперервну роботу снігоприбиральної техніки, на автошляху Київ-Одеса досі $\epsilon$ проблемні ділянки»; «У французьких Альпах рятувальники знайшли живим чоловіка, який потрапив під лавину $i$ провів під снігом майже три години»;

3) an adverb of place, for example, там: «Учора, 28 січня, сім'я туристів з Ельзасу вирушила на прогулянку на курорті Валь д’зер. Саме тоді там зійила лавина»;

4) a name of the institution: a) a name of a building: «У Гостинному дворі на Подолі хочуть створити музей сучасного мистецтва»; «В Українському інституті в Лондоні розповіли про проєкт '10 речей, які кожен має знати про Украӥну'»; b) a phrase according to the scheme: a noun denoting a generic concept (building, airport, project, network, etc.) + its name, it is possible to include an adjective denoting its belonging to a settlement, country, etc .: «Робота української художниці Уляни Сторожилової (Ulitta) представить Україну в інноваційному Міжнародному мистецькому проскті «Вічне мистецтво поза

19 Хазов П.В. Лексико-смысловые единства в строении текста (на материале газетной хроники) : дис. канд. филол. наук.www/dissercat.com. Языкознание. 1984. 268 c. 
часом» - виставичі просто неба в італійському місті Мері (Сицилія)»; «23 лютого y приміщенні столичної книгарні "Сяйво книги» відбудеться літературно-музичний вечір у рамках проєкту молодіжної літературної платформи Кабінет молодого автора НСПУ 'Творчий ковчег'».

The number of lexical and semantic units in the informative text of a news chronicle is limited, there can be a maximum of fifteen in one text. They express the following elements of the semantic structure of the text: source, place, time, event, agent, content, purpose, cause, reason, relation, reference, evaluation, result, participation, scale.

Lexical-semantic unity, according to the linguist P.V. Khazov, can be divided into mandatory, which carry the main information and form the informative core of the text, and optional, which organize the integrity of the text in combination with the lexical and semantic units of the core. Each group of texts of certain events has its own set of obligatory and optional lexical-semantic units. A sequence typical for each group of events can be represented in the corresponding scheme.

The text of the newsreel, for example, is structured as follows:

«Міністри закордонних справ (agent) України, Литви та Польщі (participation) розпочали перше засідання у форматі «Люблінського трикутника» (event), щзо проходить онлайн (place) у n'ятницю. Про иее поінформував міністр МЗС України Дмитро Кулеба (link) $у$ сочмережах. B установчій декларації три краӥни підтвердили необхідність відновлення територіальної иілісності України в межах ї̈ міжнародно визнаних кордонів, закликали Росію припинити агресію проти Украӥни і тимчасову окупацію Автономної Республіки Крим, міста Севастополь і окремих районів Донбасу, підтримали прагнення України до членства в СС і НАТО, надання Украӥні Плану дій щзодо членства в НАТО (content)».

This text can be shortened due to optional (those that do not occur in all texts) lexical-semantic units, the sequence of which can be reduced to the minimum scheme: source-participation-event-place-content.

«Як поінформував міністр МЗС України Дмитро Кулеба, міністри закордонних справ Украӥни, Литви та Польщі розпочали перще засідання у форматі «Люблінського трикутника», щзо проходить онлайн у n'ятницю. В установчий декларації три краӥни підтвердили необхідність відновлення територіальної иілісності України в межах ї міжнародно визнаних кордонів, підтримали прагнення Украӥни до членства ЕС та НАТО».

The processing of the informative text of online publications / printed press using the above-mentioned speech models / schemes can be as follows. 
Foreign students are provided with a certain informative text of the news chronicle.

«У Парижі в рамках урочистостей з нагоди 60-ї річниці прийняття ООН Загальної декларації прав людини відкрито меморіальну дошку Рафалу Лемкіну, винахідникові терміну «геноцид», повідомляє польська інформагенція ПАП. Церемонію почав міністр закордонних справ Франиії Бернар Кушнер. Саме в Парижі за день до прийняття Загальної декларації прав людини була прийнята Конвенція про запобігання злочинів геночіду, яка була фактично творінням однієї людини-професора Лемкіна.

Рафал Лемкін (1900-1959), народився в Гродненський губернії в єврейській родині. Після навчання у Львові В Університеті Яна Казімєжа провадив у Варшаві адвокатську практику. Ще в 30-х роках сформулював термін «злочини варварства», але у виданій 1944 року в США роботі змінив його на термін «геноџид». У роки Другої світової війни Лемкін утратив усю родину, тому залишив Польщу $і$ виїхав до США. Створений ним термін здобув міжнародне визнання $i$ був використаний обвинуваченням на Нюрнберзькому процесі.»

Beforehand the minimum model / scheme of this group of events is written on the board, which can be presented in the form of questions or names of lexical-semantic units:

1. (lexical-semantic unity of the place) Що було відкрито на честь винахідника терміну «геноцид»?

2. (lexical-semantic unity of time) Коли відкрито меморіальну дошку винахідникові терміну «геноиид»?

3. (lexical-semantic unity of the source of the message) Хто повідомив про відкриття меморіальної дошки винахідникові терміну «геноцид»?

4. (lexical-semantic unity of the event) Що було відкрито на честь винахідника терміну «геноиид»?

5. (lexical-semantic unity of the agent) Хто почав иеремонію відкриття меморіальної дошки?

6. (lexical-semantic unity of content) Коли був сформульований ученим термін «геноиид»?

7. (lexical and semantic unity of the result) Коли і де термін «геноцид» здобув міжнародне визнання?

At the same time, lexical tools that reflect these lexical-semantic units in the text are written on the board, and the given vocabulary is processed in the form of pre-text tasks:

Pre-text task 1. Read new words and phrases. Using a dictionary, translate into your native language. Write them down and remember them.

Меморіальна дошка, иеремонія, винахідник, урочистості, справи, Загальна декларація прав людини, ООН, сформулювати, термін 
«злочини варварства», створити, використати, здобувати, міжнародне визнання, Нюрнберзький проиес.

Pre-text task 2. Determine the gender and number of the given nouns: дошка, винахідник, злочин, урочистості, декларачія, термін, людина, права, визнання.

Pre-text task 3. Choose the appropriate nouns for the given verbs using the text. Model: відкрито (що?) дошку, иеремонію.

Сформулювати (що?), створити (щэо?), здобувати (щчо?), використати (де?).

Pre-text task 4. Using the text, select appropriate adjectives for the given nouns. Model: дошка (яка?) меморіальна.

Інформагениія (яка?), декларачія (яка?), справ (яких?), війна (яка?), визнання (яке?), проиес (який?).

After studying the vocabulary, students read the proposed text.

Task 5. Read the text of the news chronicle «Він придумав слово «геноиид».

Then, following the scheme (written on the board in the form of a questionnaire), students restore the text according to this scheme / model, introduce other most commonly used variants of lexical-semantic units used in the group of events considered and written by the teacher on the board. That is, foreign students perform post-text tasks.

Post-text task 6. Write the answers to the questions written on the board in the form of a question plan.

Post-text task 7. Retell the news you have just read to your friends (using your notes).

\section{CONCLUSIONS}

Thus, in the minds of students, the semantic structure of the text and its lexical embodiment are interrelated. In the future, students can perform tasks for transformation, i.e. the replacement of one version of lexical-semantic units with another in the processing of informative texts of news chronicles containing similar lexical-semantic units.

Models / schemes of texts are typical variants of arrangement of lexicalsemantic units, such as: source-time-place-event-agent-link-content. Although in a certain informative text a different order of lexical-semantic units is possible. Students, processing the text, retell it in accordance with the proposed model / scheme. The next stage is transformation, i.e. students are offered a text that differs from the model under consideration.

Thus, the didactic goal of processing the informative text of news chronicles of online publications / printed press is achieved - it is the understanding of the text and its reproduction, retelling. 
Summarizing the above, we can conclude that productive reading of informative media texts is one of the priority practical tasks of teaching Ukrainian as a foreign language in higher education institutions of Ukraine. The role of reading in the educational process is difficult to overestimate because due to the productivity of this process the student masters speech material of a foreign language, works on certain topics to prepare an oral presentation, enriche their worldview with knowledge of history, culture and life of the people they study.

According to the results of our study, it can be stated that informative texts of news chronicles of online publications/ printed press should correspond to the level of speech competence of students; should contain a problem and have a clear structure, as the text is used not only as means of teaching reading, but also for the formation of other productive skills: orientation in the text, mental processing of new information and learning to review.

\section{SUMMARY}

The article considers the features of the media text of news chronicles as a material for teaching reading to foreign students. The expediency of using the method of creating speech models of media texts of news chronicles is analyzed, which will allow students to systematize lexical material, structure it in accordance with certain components of the text structure, master the semantic structure of the text with its specific language features. The mechanisms of practicing reading with the help of speech models of media text and production of other skills related to both reception (model as a reference point when reading a text) and reproduction (model as a reference point when translating a text) are clarified.

Productive reading of informative media texts is one of the priority practical tasks of teaching Ukrainian as a foreign language in higher education institutions of Ukraine. The role of reading in the educational process is difficult to overestimate, because due to the productivity of this process the student masters the speech material of a foreign language, works on certain topics to prepare an oral presentation, enriche their worldview with knowledge of history, culture and life of the people they study.

\section{REFERENCES}

1. Станкевич Н.I. Види читання в курсі української мови як іноземної. Теорія і практика викладання української мови як іноземної. 2013. № 8. C. 186.

2. Селіванова О.О. Сучасна лінгвістика: напрями та проблеми. Підручник. Полтава : Довкілля-К, 2008. 713 с. 
3. Іщенко Н.Г. Текст- цілісна мовна й мовленнєва структура. Науковий вісник ДДПГУ імені I. Франка. Серія "Філологічні науки». Мовознавство. Том 1. № 5, 2016.

4. Леонтьев А.А. Восприятие текста как психологический процесс. Психолингвистическая и лингвистическая природа текста и особенности его восприятия. Київ : Вища школа,1979. С.23.

5. Чепелєва Н.В. Текст і читач: посібник. Житомир : Вид-во ЖДУ імені І. Франка, 2015.124с.

6. Українська мова. Енциклопедія \редкол.: В.М. Русанівський та ін. Київ : Українська енциклопедія ім. М. Бажана, 2000. 752c.

7. Селиванова О.О. Лінгвістична енциклопедія. Полтава : Довкілля-К, 2010.844 с.

8. Чередниченко І.Г. Стиль масової преси. Нариси з загальної стилістики сучасної украӥнської мови. Київ, 1962. С. 51-52.

9. Зайцева В.В. Особливості газетно-публіцистичного стилю. Дослідження з лексикології і граматики украӥнської мови. 2001. С. 82-91.

10. Алексеев А.Я. Сопоставительная стилистика: уч. пособие. Днепропетровск : Национальный горный университет, 2012.471c.

11. Зайцева В.В. Про жанрову своєрідність газетної мови. Украӥнський смисл. 2015. С. 39.

12. Хазов П.В. Лексико-смысловые единства в строении текста (на материале газетной хроники) : дис. канд. филол. наук www/dissercat.com. Языкознание. 1984. 268 с.

\section{Information about the author:} Zanko O. V.,

Senior Lecturer at the Department of Applied Linguistics National University "Odesa Law Academy" 23, Fontanska doroha str., Odesa, 65009, Ukraine 